\title{
Fruit Morphology, Antioxidant Activity, Total Phenolic and Flavonoid Contents of Salacca zalacca (Gaertner) Voss by Applications of Goat Manures and Bacillus velezensis B-27
}

\author{
Haviah Hafidhotul Ilmiah ${ }^{1 *}$, Endang Sulistyaningsih ${ }^{1}$ and Tri Joko ${ }^{2}$ \\ ${ }^{1}$ Department of Agronomy, Faculty of Agriculture, Universitas Gadjah Mada, Yogyakarta, Indonesia; \\ ${ }^{2}$ Department of Plant Protection, Faculty of Agriculture, Universitas Gadjah Mada, Yogyakarta, Indonesia \\ *Corresponding author: haviah@ugm.ac.id
}

\begin{abstract}
Snake fruit (Salacca zalacca (Gaertner) Voss) is one of indigenous fruits from Southeast Asia that has been consumed for its antioxidant contents. Improving the fruit quality might increase its benefits for human health. This study aims to analyze fruit morphology, antioxidant activity, total phenolic and flavonoid contents of the fruit applied with goat manures and Bacillus velezensis B-27. The research used two-factor Randomized Complete Block Design (RCBD) with three blocks as replications. The first factor is the level of goat manure application i.e. $0 \mathrm{~kg}_{\text {plant }}{ }^{-1}, 5 \mathrm{~kg} \mathrm{plant}^{-1}$ and $10 \mathrm{~kg} \mathrm{plant}^{-1}$, while the second factor is the bacteria application i.e. applied with Bacillus velezensis B-27 and without Bacillus velezensis B-27. The research was conducted in June until December 2019 at Turi, Sleman, Yogyakarta, Indonesia. Fruit length, diameter and shape were measured as morphology parameters. Antioxidant activities were measured using 2,2-Diphenyl-1-picrylhydrazyl, whereas flavonoid and phenolic contents were determined by the aluminium-chloride colorimetric and Folin-Ciocalteu methods, respectively. Means of each parameter were analyzed using ANOVA, continued with the Tukey's HSD test at a 5\% significance level. The result showed that the application of $10 \mathrm{~kg}$ goat manure per plant with bacteria increased the fruit length $(76.78 \mathrm{~mm})$ and the diameter $(62.72 \mathrm{~mm})$. Addition of $10 \mathrm{~kg}$ goat manure per-plant combined with Bacillus velezensis B-27 gave the highest antioxidant (IC50 of $37.83 \mu \mathrm{g} \mathrm{mL}^{-1}$ ), flavonoid (5.35 mgGAE $100 \mathrm{~g}^{-1}$ ) and total phenolic contents (44 mgQE $100 \mathrm{~g}^{-1}$ ).
\end{abstract}

Keywords: antioxidant; flavonoid; goat manure; indigenous fruits; phenolic; snake fruit

Cite this as: Ilmiah, H. H., Sulistyaningsih, E., \& Joko, T. (2021). Fruit Morphology, Antioxidant Activity, Total Phenolic and Flavonoid Contents of Salacca zalacca (Gaertner) Voss by Applications of Goat Manures and Bacillus velezensis B-27. Caraka Tani: Journal of Sustainable Agriculture, 36(2), 270-282. doi: http:// dx.doi.org/10.20961/carakatani.v36i2.43798

\section{INTRODUCTION}

Salacca zalacca (Gaertner) Voss, usually called snake fruit, is an indigenous exotic fruit from Southeast Asia such as Indonesia, Malaysia, Thailand and Brunei Darussalam that belongs to the palm group (Family: Arecaceae). It has reddish-brown scaly skin like snake and creamywhite fruit, which has honey-like taste (Saleh et al., 2018). In Indonesia, the snake fruit is an important fruit commodity, with the total production of snake fruit of 2.896 quintal year ${ }^{-1}$ (BPS - Statistics Sleman Regency, 2018). This underutilized fruit remains an issue about future sustainable utilization and commercial value enhancement, which the fruits are actually popular across international markets within South East Asia (Mazumdar et al., 2019).

\footnotetext{
* Received for publication August 17, 2020

Accepted after corrections May 3, 2021
} 
One of the problems is the lack of fruits quality because of inadequate cultivation practices, where the farmers rarely give attention to soil nutrition needed for plant growth and development. It also results in soil fertility and fruit productivity. The farmers have only used snake fruit leaves that have dried up as fertilizer (Adijaya and Yasa, 2015). Therefore, it is necessary to increase the fertility of land that utilizes familiar materials, such as the use of manure. There is goat manure, a kind of fertilizer that is important for increasing the growth of plant (Hariadi et al., 2016). The goat manure contains the highest macronutrients contents, such as $2.77 \%$ nitrogen, $1.78 \% \mathrm{P}_{2} \mathrm{O}_{5}$ and $2.88 \% \mathrm{~K}_{2} \mathrm{O}$, among other animal manures (Chatzistathis et al., 2020). Mowa et al. (2017) have suggested that organic nutrients from goat manure can improve plant growth and yield performance of tomato. Nitrogen in fertilizer is one factor that affects the quality of the fruits (Lyu et al., 2019).

Moreover, the snake fruit is an excellent antioxidant source whose activities are higher compared to kiwifruit (Gorinstein et al., 2009; Saleh et al., 2018). Tilaar et al. (2017) have stated that several studies have proved that snake fruit has antioxidant activity that can be used for any purposes. The methanol extracts of the fruits showed a high antioxidant activity accompanied by its anti-hypertensive and anti-diabetic effects (Tan et al., 2020). Suica-Bunghez et al. (2016) revealed that the antioxidant activity of snake fruit is caused by the content of polyphenol, flavonoid, tannin and monoterpenoid compounds. Increasing the group of these chemical compounds will gain the benefits for the consumer of the fruit. However, the use of synthetic chemicals to improve fruit yield and phytochemical contents of snake fruits is known to have adverse effects both on health and environment. Thus, several studies to improve yield and quality of snake fruits by applying eco-friendly treatment are advisable.

In terms of the antioxidant properties, the application plant growth-promoting rhizobacteria (PGPR), like Bacillus sp., can increase the antioxidant activity of fruit by increasing some metabolites level, such as phenolics and flavonoids (Rahman et al., 2018). Song et al. (2015) declared that PGPR can improve the plant root structure that gives positive effect on the fruit quality. In addition, Bacillus velezensis, an important PGPR, can promote the plant growth by producing some organic acids, ACC deaminase, the phytohormone indole-3-acetic acid (IAA) and siderophores, as well as and help nitrogen fixation and phosphate solubilization. Furthermore, the plants applied with the bacteria show growth and flowering improvement. Besides, PGPR exhibits antifungal activities and thus, has immense potency to support sustainable agriculture by minimizing fungicide use (Tiwari et al., 2019). According to Santos-sanchez et al. (2018), biosynthesis of antioxidant compounds, like polyphenol, flavonoid and tannin, occurs by shikimic acid pathway that begins with condensation of phosphoenolpyruvic acid, which is the result of glycolysis pathway. The pyruvate metabolism is one of important pathways in arillus of snake fruit (Fendiyanto et al., 2020). The nitrogen in the soil also gives some effects on glycolysis pathway that forms the pyruvate. Nevertheless, a few studies evaluate the metabolite levels as the results of fertilizer treatment (Iqbal et al., 2020).

Organic farming has become very interesting to change the old farming technique that uses non-natural chemicals in agricultural cultivation into an eco-friendly one. The organic farming also helps the consumers to obtain health organic products that can only be produced by organic farming method. However, in order to increase soil fertility, the use of organic matter still faces some challenges, such as a high ratio of organic fertilizer $\mathrm{C} / \mathrm{N}$, where the contents of complex compounds are higher than elements that can be absorbed by the roots of plants (Mayrowani, 2016). Therefore, combining fertilization with biological agent activities such as PGPR becomes one of the alternative solutions. Complex nutrients in manure will be broken down by PGPR as materials for metabolic activities so that there are elements that can be absorbed by the roots of plants. This combination is expected to increase the productivity and phytochemical properties of the snake fruit, without disrupting the environmental sustainability (Reddy et al., 2019; Sharma et al., 2019). However, studies investigating the effects of PGPR combined and goat manure to snake fruit are scarce, although it is highly important to increase fruit quality. Hence, in this present study, the combination of goat manure and PGPR that can improve the quality of snake fruits, both morphologically and for increasing its phytochemical contents is determined. 


\section{MATERIALS AND METHOD}

\section{Experimental site and materials}

The experimental field of this study was located at "Si Cantik" organic snake fruit orchad, Ledoknongko Village, Turi, Sleman, Special Region of Yogyakarta, from June until December 2019 (7.650S and 110.360E). Meanwhile, the laboratory analysis was conducted in Horticulture Sub-laboratory, Faculty of Agriculture, Universitas Gadjah Mada.

The main materials used were the plants of snake fruit (Salacca zalacca var. pondoh) aged 20 years old, goat manures and Bacillus velezensis. The goat manures contained $0.32 \%$ of nitrogen, $24 \mathrm{ppm}$ of phosphate, $0.59 \mathrm{Cmol} \mathrm{kg}^{-1}$ of potassium, with the $\mathrm{pH}$ value was 8.0 (Gichaba et al., 2020). The bacteria used in this study were Bacillus velezensis B-27 using gryB primers identification (Rahma et al., 2020).

\section{Experimental design and procedures}

\section{Experimental design}

The field experiment was laid out in a factorial randomized complete block design with two factors and three blocks as replications. The first factor was the level of goat manure application i.e. $0 \mathrm{~kg}$ plant $^{-1}, 5 \mathrm{~kg}$ plant $^{-1}$ and $10 \mathrm{~kg}$ plant $^{-1}$. The second factor was Bacillus velezensis $\mathrm{B}-27$ treatment i.e. Bacillus velezensis B-27 treatment and without bacteria treatment. There were six combinations of treatments for each block i.e. $0 \mathrm{~kg}$ goat manure per-plant without Bacillus velezensis $\mathrm{B}-27$ ( $\mathrm{P} 0 \mathrm{~B} 0), 0 \mathrm{~kg}$ goat manure per-plant with bacteria (P0B1), $5 \mathrm{~kg}$ goat manure per-plant without bacteria (P1B0), $5 \mathrm{~kg}$ goat manure per-plant with bacteria (P1B1), $10 \mathrm{~kg}$ goat manure per-plant without bacteria (P2B0), $10 \mathrm{~kg}$ goat manure per-plant with bacteria (P2B1).

\section{Procedures}

\section{Goat manure application}

The goat manures were applied to the plants based on the experimental design. The manure application adopted the ring method developed by Adijaya and Yasa (2015) with several modifications, by making a circle hole around the tree approximately $50 \mathrm{~cm}$ from the base of the trunk. The goat manure was applied once after pollination using ring method at the day of pollination because nitrogen is one of factors affecting the viable of ovules including the fertilization (Hill-Cottingham and Williams, 2015).

Preparation and application of bacterial suspension

Bacillus velezensis $\mathrm{B}-27$ isolates were cultured in $500 \mathrm{~mL}$ liquid media in the form of nutrient broth (NB) in conical tubes. Each tube was placed in a shaking incubator with a speed of $150 \mathrm{rpm}$ and a temperature of $27^{\circ} \mathrm{C}$ for 48 hours for bacterial growth. The bacterial solution was then centrifuged at a speed of $12,000 \mathrm{~g}$ and the pellets were washed with distilled water for three times to remove the nutrients from the media. Bacterial pellets were suspended in water and diluted to a concentration of $1 \times 109$ $\mathrm{CFUmL}^{-1}$. Bacterial application was performed by hoeing the soil near the roots and then the bacterial solution was splashed to the roots and leaked at the base of the stem near the roots. The Bacillus velezensis B-27 was treated once a week for seven times, began at the day the goat manure applied.

\section{Fruit harvesting and extraction}

Fruits were harvested 5.5 months after pollination when the smooth thorns of the fruit skin were starting rarely. Then, the fruits were extracted to ensure that polyphenol and flavonoid compounds could be separated from fruit tissue. The extraction also minimized the degradation of polyphenols due to phenolase enzyme activity. The solvent used was $96 \%$ ethanol with a volume of $2 \mathrm{~mL}$ for $2 \mathrm{~g}$ of fruit samples. As much as $2 \mathrm{~g}$ of snake fruit was crushed with pestle and mortar until smooth then dissolved in $2 \mathrm{~mL}$ of $96 \%$ ethanol. The fruit solution in ethanol was then heated with a temperature of $70^{\circ} \mathrm{C}$ for 1 hour and filtered using filter paper to produce fruit extracts. Extract storage was carried out at $-20^{\circ} \mathrm{C}$ (Belwal et al., 2019).

\section{Measurement of fruit morphology}

Diameter, length and shape of fruit were measured as the morphology parameters. The diameter was determined from the horizontal axis of fruit, whereas length was measured by the vertical axis (Figure 1). The shape of the fruit was quantitatively measured by the scoring method. The score of the fruit shape was determined by giving a score of 1 for the fruit with flattened shape, while the score of 2 for oval shape and a score of 3 for round shape. 
Good quality fruit has a shape that tends to be rounded so that it received the highest score (Nurrochman et al., 2013).

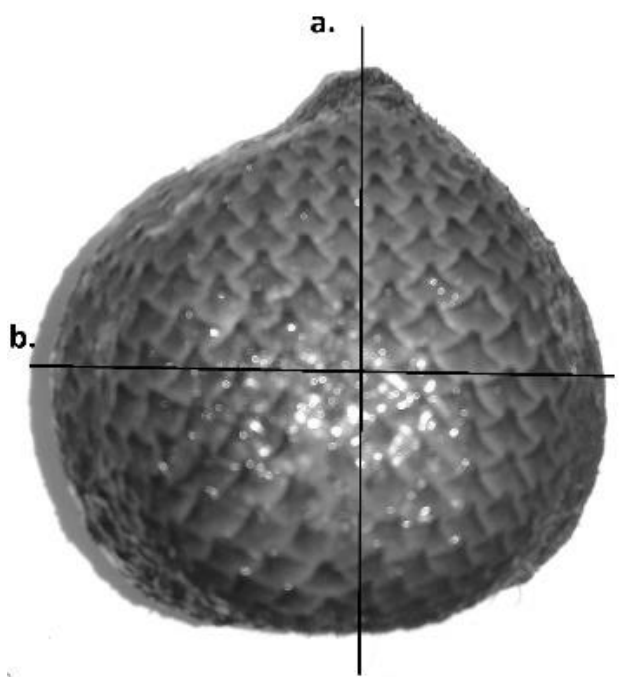

Figure 1. Morphology diagram of snake fruit: a. the fruit length, $b$. the fruit diameter

Antioxidant Activity Assay using 2,2-Diphenyl-1picrylhydrazyl

The antioxidant activities were measured by modifying the 2,2-diphenyl-1-picrylhydrazyl (DPPH) method (Jimoh et al., 2019). Snake fruit extracts were made in seven concentrations, namely $120,100,80,60,40,20$ and $10 \mu \mathrm{g} \mathrm{mL}^{-1}$. As much as $2 \mathrm{ml}$ of snake fruit extract at each concentration was added with $2 \mathrm{~mL}$ of a $0.1 \mathrm{mM}$ DPPH solution and then incubated for 30 minutes in a dark place. The absorbance of the solution was measured by a UV-Vis spectrophotometer with a wavelength of $517 \mathrm{~nm}$. The value of \% inhibition was then measured using absorbance values that have been measured by the formula: Note:

$$
\% \text { inhibition }=[(\mathrm{A} 0-\mathrm{As}) / \mathrm{A} 0] \times 100 \%
$$

A0 $=$ DPPH solution without sample

As $\quad=$ DPPH solution with sample

A regression equation between $\%$ inhibition and concentration was sought to measure the antioxidant activity. The antioxidant activity of the sample was expressed by the inhibition of free radical DPPH by 50\% (IC50). IC50 value indicates a sample concentration that can inhibit DPPH free radicals by as much as $50 \%$, so it can be used to show the antioxidant activity of a solution (X) from the regression equation. DPPH test with quercetin was also performed as a comparison.

\section{Measurement of flavonoid content}

Flavonoid content was measured by aluminium-chloride colorimetric method proposed by Chang et al. (2002), with modification. First, a standard quercetin curve was created by preparing six series of aqueous quercetin solution with the concentration of 20, 40, 60, 80, 100 and $120 \mu \mathrm{g} \mathrm{mL}^{-1}$. Then, $0.5 \mathrm{~mL}$ of each solution was mixed with $1.5 \mathrm{~mL}$ ethanol $95 \%, 0.1 \mathrm{~mL} \mathrm{KCH}_{3} \mathrm{COOH} 1 \mathrm{M}$ and 2.8 distilled water and then incubated for 30 minutes at $25^{\circ} \mathrm{C}$. Absorbance of the solutions was measured by a UV-Vis spectrophotometer at a wavelength of $415 \mathrm{~nm}$. The standard equation was determined by regression between the absorbance and concentration of quercetin. Second, flavonoid contents were measured by the same step with flavonoid content of quercetin. The value of flavonoid contents was determined using the standard equation and expressed as milligram flavonoid per-100 gram of sample $\left(\mathrm{mgQE} 100 \mathrm{~g}^{-1}\right)$.

\section{Measurement of total phenolic content}

Total phenol contents were determined using the Folin-Ciocalteu method with some modifications based on Zargoosh et al. (2019) with gallic acid as standard. A series of gallic acid with a concentration of $1.1 ; 2.2 ; 3.3 ; 4.4 ; 5.5 ; 6.6$; $7.7 ; 8.8 ; 9.9 ; 10.10$ and $11 \mathrm{mg} \mathrm{mL}^{-1}$ were prepared to make a standard curve. Briefly, each of standard $(1 \mathrm{~mL})$ and extract $(1 \mathrm{~mL})$ were placed in different test tubes and three $\mathrm{mL}$ of distilled water, $100 \mu \mathrm{l}$ of Folin-ciocalteu reagent were added and mixed and then incubated for three minutes. Next, $300 \mu \mathrm{Na}_{2} \mathrm{CO}_{3} 2 \%$ was mixed and then added with ethanol until reaching a total volume of $5 \mathrm{~mL}$. After that, each solution was incubated for two hours at $25^{\circ} \mathrm{C}$ and absorbance was measured by a UV-Vis spectrophotometer at a wavelength of $760 \mathrm{~nm}$. Total phenol content was expressed as milligram phenol per-100 gram of sample (mgGAE $\left.100 \mathrm{~g}^{-1}\right)$.

\section{Data analysis}

Mean of each parameter was analyzed using Analysis of Variance (ANOVA) continued with Tukey's HSD test at 5\% of significance level. Then, the antioxidant activity, flavonoid and total phenolic contents were correlated using correlation test with SPSS 16.0. 


\section{RESULTS AND DISCUSSION}

\section{Fruit morphology}

Measurement of fruit length, diameter and shape score was conducted as morphological parameter of fruit quality. The data of length of the fruits are shown in the following Table 1. Based on Table 1 presents that the levels of goat manure applications and bacteria treatments showed a positive interaction to increase the fruit length. The best treatment of all was the application of $10 \mathrm{~kg}$ goat manure per-plant combined with Bacillus velezensis $\mathrm{B}-27$. Then, by comparing the Bacillus velezensis B-27 treatment and control, we got that bacteria could significantly increase the fruit length.

Table 1. Fruit length of snake fruit by goat manure and Bacillus velezensis B-27 applications

\begin{tabular}{|c|c|c|c|c|}
\hline \multirow{3}{*}{$\begin{array}{l}\text { Bacillus velezensis B-27 } \\
\text { applications }\end{array}$} & \multicolumn{3}{|c|}{ Fruit length (mm) } & \multirow{3}{*}{$\begin{array}{c}\text { The average of fruit length } \\
\text { by Bacillus velezensis B-27 } \\
\text { treatments }(\mathrm{mm})\end{array}$} \\
\hline & \multicolumn{3}{|c|}{ Goat manure level (kg per-plant) } & \\
\hline & 0 & 5 & 10 & \\
\hline Without Bacillu & $53.73 \mathrm{f}$ & $57.17 \mathrm{e}$ & $67.18 \mathrm{c}$ & 59.36 \\
\hline With Bacillus velezensis B-27 & $64.74 \mathrm{~d}$ & $69.33 \mathrm{~b}$ & $76.78 \mathrm{a}$ & 70.28 \\
\hline $\begin{array}{l}\text { The average of fruit length by goat } \\
\text { manure treatments }(\mathrm{mm})\end{array}$ & 59.24 & 63.25 & 71.98 & $(+)$ \\
\hline
\end{tabular}

Coefficient of variance $(\%)$

12.14

Note: Mean values followed by the same letters are not significantly different at $p<0.05$ according to Tukey's HSD test. A positive sign (+) shows positive interaction between two factors

The following Table 2 figure out that goat manure and Bacillus velezensis B-27 gave a positive interaction to increase the fruit diameter.
The application of $10 \mathrm{~kg}$ goat manure per-plant with Bacillus velezensis B-27 could significantly improve the diameter of the fruit.

Table 2. Fruit diameter of snake fruit by goat manure and Bacillus velezensis B-27 applications

\begin{tabular}{|c|c|c|c|c|}
\hline \multirow{3}{*}{$\begin{array}{l}\text { Bacillus velezensis } \\
\text { B-27 applications }\end{array}$} & \multicolumn{3}{|c|}{ Fruit diameter $(\mathrm{mm})$} & \multirow{3}{*}{$\begin{array}{c}\text { The average of fruit diameter } \\
\text { by Bacillus velezensis B-27 } \\
\text { treatments }(\mathrm{mm})\end{array}$} \\
\hline & \multicolumn{3}{|c|}{ Goat manure level (kg per-plant) } & \\
\hline & 0 & 5 & 10 & \\
\hline Without Bacillus velezensis B-27 & $36.92 \mathrm{e}$ & $43.44 \mathrm{~d}$ & $48.13 \mathrm{c}$ & 59.36 \\
\hline With Bacillus velezensis B-27 & $47.55 \mathrm{c}$ & $58.85 \mathrm{~b}$ & $62.72 \mathrm{a}$ & 70.28 \\
\hline $\begin{array}{l}\text { The average of fruit diameter by } \\
\text { goat manure treatments }(\mathrm{mm})\end{array}$ & 42.24 & 51.15 & 55.43 & $(+)$ \\
\hline Coefficient of variance (\%) & & 18.55 & & \\
\hline
\end{tabular}

Table 2 demonstrates that the application of Bacillus velezensis B-27 without manure still gave longer diameter than the application of $5 \mathrm{~kg}$ goat manure per-plant. The Bacillus velezensis B-27 addition also increased the fruit diameter compared with the application without bacteria. This indicates that the bacteria supplement could be an alternative to make the nutrients absorption more efficient.

The score of fruit shape signified the quality of fruit, in which the highest value represented round shape fruit. The application of goat manure and Bacillus velezensis B-27 did not show positive interaction to make the shape score higher than control. From Table 3, we could see that the level of manure that gave a significantly higher value than control was $10 \mathrm{~kg}$ goat manure per-plant. Based on (Handajaningsih et al., 2019), incorporating organic matter like goat manure can improve soil fertility, then increase the fruit weight and diameter in Cucumis melo $\mathrm{L}$.

For the Bacillus velezensis B-27 application to the plant, the score for the shape did not show the significant improvement from the application with bacteria and without bacteria. However, compared with control treatment of manure, added $10 \mathrm{~kg}$ goat manure per-plant could enhance the score of the shape, meaning that the fruit tended to be rounded than flattened. 
Commercially, farmer sorted the rounded fruit as the best grade of snake fruits (Nurrochman et al., 2013).

Table 3. Fruit shape scoring of snake fruit by goat manure and Bacillus velezensis B-27 applications

\begin{tabular}{lc}
\hline \multicolumn{1}{c}{ Treatments } & $\begin{array}{c}\text { Shape } \\
\text { score }\end{array}$ \\
\hline Goat manure level & \\
0 kg per-plant & $1.83 \mathrm{~b}$ \\
$5 \mathrm{~kg}$ per-plant & $2.33 \mathrm{ab}$ \\
10 kg per-plant & $2.83 \mathrm{a}$ \\
Bacillus velezensis $\mathrm{B}-27$ applications & \\
Without Bacillus velezensis B-27 & $1.89 \mathrm{p}$ \\
With Bacillus velezensis $\mathrm{B}-27$ & $2.78 \mathrm{p}$ \\
Interaction & $(-)$ \\
\hline CV $(\%)$ & 34.08 \\
\hline N &
\end{tabular}

Note: Mean values followed by the same letters are not significantly different at $\mathrm{p}<0.05$ according to HSD-Tukey Test. A negative sign (-) showed negative interaction between 2 factors

The application of goat manure combined with Bacillus velezensis B-27 gave variation to the size and shape of the fruits. The illustration of the fruit morphology can be seen in Figure 2. Improvement of size and shape are affected by nutrition supply of manure and microbial activity of Bacillus velezensis B-27 through inclination of phytohormones level (Rahman et al., 2018).

The fruit morphology of the snake fruit shows an improvement for the size and shape of goat manure and Bacillus velezensis B-27 treatments, compared with control treatment (Figure 2). This study gave the same result as the study by Wang et al. (2020), which figured out that Bacillus sp. could improve the morphology of banana fruit, including the length and diameter of the fruit. The banana root exudate might enhance the colonization of the bacteria, whereas they could produce auxin as a plant growth regulator. Another study from Gül et al. (2008), also reported a consistent result, revealing that Bacillus sp. treatment for tomatoes could increase the fruit diameter and thus increased marketable fruits. Rahma et al. (2020) confirmed that Bacillus velezensis strain B-27 could significantly reduce disease infections and improved vegetative growth and yield of shallot. However, goat manure and Bacillus velezensis B-27 did not give significant effect on the fruit shape (Table 3). The shape might be encoded by complex genes that bring up shape character. Hence, to improve the shape quality of fruits needs a combination with another technique like phytohormone application to induce fruit growth to reach maximum shape. a

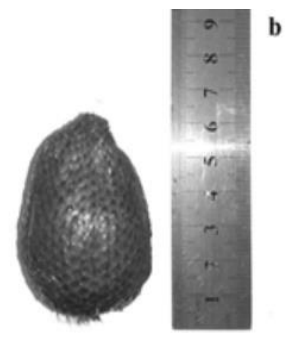

d
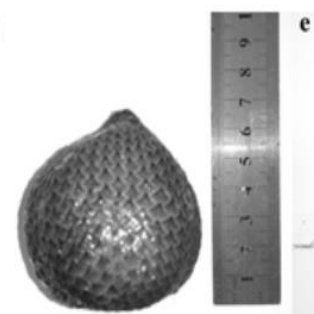
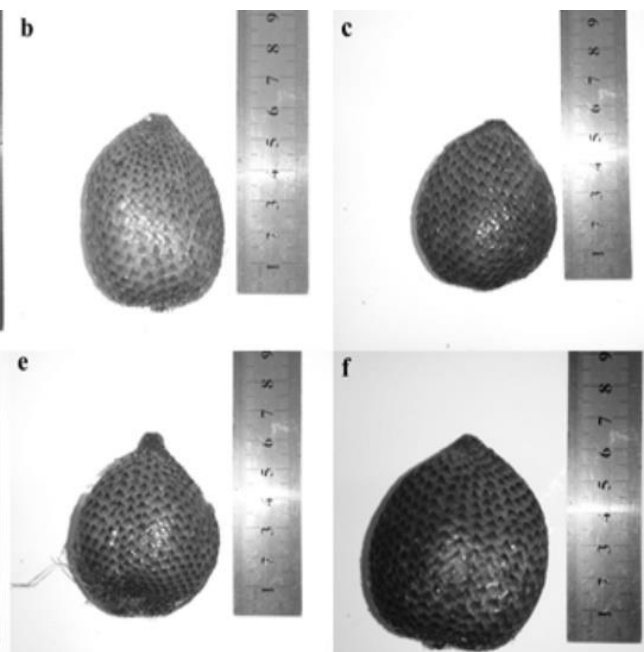

Note: $\mathrm{a} . \mathrm{P} 0 \mathrm{~B} 0=0 \mathrm{~kg}$ per-plant of goat manure without Bacillus velezensis $\mathrm{B}-27$; $\mathrm{b} . \mathrm{P} 0 \mathrm{~B} 1=0 \mathrm{~kg}$ perplant of goat manure + Bacillus velezensis $\mathrm{B}-27 ; \mathrm{c}$. $\mathrm{P} 1 \mathrm{~B} 0=5 \mathrm{~kg}$ per-plant of goat manure without Bacillus velezensis $\mathrm{B}-27$; d. P1B1 $=5 \mathrm{~kg}$ per-plant of goat manure + Bacillus velezensis $\mathrm{B}-27$; e. $\mathrm{P} 2 \mathrm{~B} 0=10 \mathrm{~kg}$ per-plant of goat manure without Bacillus velezensis $\mathrm{B}-27$; $\mathrm{f}$. $\mathrm{P} 2 \mathrm{~B} 1=10 \mathrm{~kg}$ perplant of goat manure + Bacillus velezensis B-27

Figure 2. Fruit morphology by the application of goat manure combined with Bacillus velezensis B-27 
Using microbial treatment in agriculture remains a challenge because we should choose suitable species of bacteria to increase the yield. However, the study to determine the effects of PGPR to enhance the quality and quantity of plant production is still required, especially to realize the sustainable agriculture. Cultivation technique using organic substances and biological agents is an alternative to improve plant growth and combat some abiotic stresses or pathogens. Some studies have noted that Bacillus sp. can increase fruit quality (Rahman et al., 2018). The growth and development improvement induced by Bacillus sp. are mostly affected by indole-acetic-acid produced by the bacteria and through their ability to overcome several stresses caused by environment or pathogen like Pseudomonas sp. (Albanchez et al., 2018). Subsequently, the Bacillus sp. treatment was also reported to decrease ring rot disease in apple fruit, as a postharvest handling method of the fruits (Li et al., 2013). For the postharvest treatment of snake fruit, the effect of Bacillus sp. to inhibit the activity of pathogenic microbes is necessary to be analyzed in snake fruit.

\section{Antioxidant activity}

The DPPH test of snake fruit represent how fruit extracts can scavenge $50 \%$ of DPPH radicals. The measured value was defined as IC50. The IC50 value is opposite with antioxidant activity. The high IC50 value means low antioxidant activity (Oubihi et al., 2020). The results reveal that the snake fruits with $10 \mathrm{~kg}$ goat manure per-plant and Bacillus velezensis B-27 applications had the highest antioxidant value of all treatments although it was insignificantly different with antioxidant activity of quercetin as positive control and snake fruit with $10 \mathrm{~kg}$ goat manure and without Bacillus application (Figure 3).

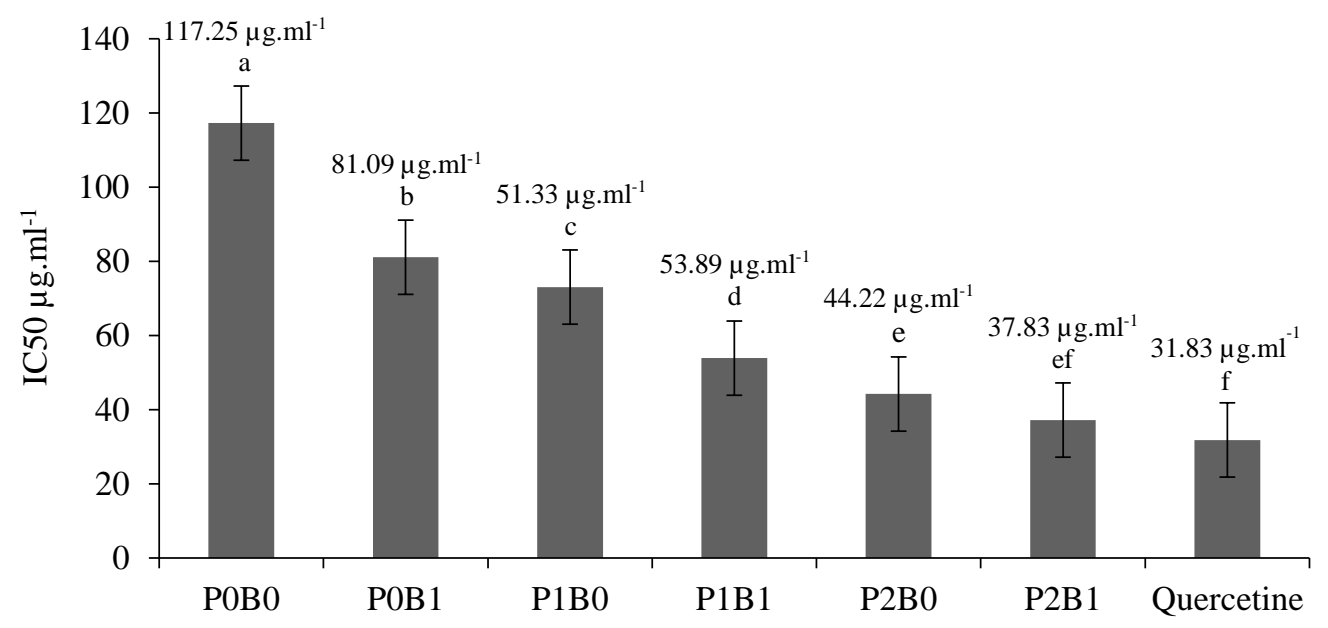

Note: Mean values followed by the same letters are not significantly different at $\mathrm{p}<0.05$ according to Tukey's HSD test. $\mathrm{P} 0 \mathrm{~B} 0=0 \mathrm{~kg}$ per-plant goat manure without Bacillus velezensis $\mathrm{B}-27$; $\mathrm{P} 0 \mathrm{~B} 1=0 \mathrm{~kg}$ per-plant goat manure + Bacillus velezensis $\mathrm{B}-27 ; \mathrm{P} 1 \mathrm{~B} 0=5 \mathrm{~kg}$ per-plant goat manure without Bacillus velezensis $\mathrm{B}-27$; $\mathrm{P} 1 \mathrm{~B} 1=5 \mathrm{~kg}$ per-plant goat manure + Bacillus velezensis $\mathrm{B}-27 ; \mathrm{P} 2 \mathrm{~B} 0=10$ kg per-plant goat manure without Bacillus velezensis $\mathrm{B}-27 ; \mathrm{P} 2 \mathrm{~B} 1=$ $10 \mathrm{~kg}$ per-plant goat manure + Bacillus velezensis $\mathrm{B}-27$

Figure 3. Antioxidant activity of snake fruit treated with three levels of goat manure and Bacillus velezensis $\mathrm{B}-27$ compared with quercetin as standard

As a result, application of $10 \mathrm{~kg}$ goat manure per-plant could increase the antioxidant value of snake fruit and then its combination with Bacillus velezensis B-27 also produced higher the IC50 value. Salehi et al. (2019) found that the increase of the antioxidant activity by the applications of goat manure may be caused by the existence of organic manure in providing macronutrients, such as nitrogen, phosphorus and potassium that have a role for antioxidant activity. According to Rahman et al. (2018), giving Bacillus velezensis B-27 treatment in the roots of strawberry plants produced higher antioxidant activity than the treatment 
without bacteria. Therefore, the combination of goat manures and Bacillus velezensis B-27 treatments possibly increase the substances engaged in the synthesis process of some secondary metabolite pathways. As reported before, using microbes can enhance some genes in the phenylpropanoid pathway that result in increased flavonoid compounds (Ali and McNear, 2014). In line with the report of Leontowicz et al. (2006), the IC50 value of snake fruit without any treatment was $72.9 \mu \mathrm{g} \mathrm{mL} \mathrm{m}^{-1}$, representing lower antioxidant activity than the fruit with goat manure and Bacillus velezensis B-27 applications.

Treating snake fruit with Bacillus velezensis B-27 showed higher antioxidant than control and then combined it with goat manure produced the best result (Figure 1). Kadaikunnan et al. (2015) revealed that active compound in the cell surface of Bacillus sp. contains some antioxidant enzymes like NADH-oxidase, SOD, NADH peroxide and non-heme catalases.
Since antioxidant comprises chain-breaking antioxidants like phenols and flavonoids and also antioxidant enzymes (Pisoschi et al., 2021), increasing the secondary metabolites and enzymes by Bacillus sp. can enhance antioxidant activity to reduce oxidative stress. We know that society consume fruits not only to enjoy the delicious taste but also to take several substances that are beneficial for health, including antioxidant substances, that can improve antioxidant activity by bio-fertilizers and substitute synthetic inputs, which can decrease physical texture of the soil.

\section{Flavonoid contents}

The flavonoid content figured out the concentration of flavonoid compounds that equivalent to quercetin per-100 gram of samples. Positive interaction was showed by the goat manure level and Bacillus velezensis B-27 application to increase the flavonoid content of snake fruit (Table 4).

Table 4. Flavonoid content of snake fruit by applications of goat manure and Bacillus velezensis B-27

\begin{tabular}{|c|c|c|c|c|}
\hline \multirow{2}{*}{$\begin{array}{l}\text { Bacillus velezensis B-27 } \\
\text { applications }\end{array}$} & \multicolumn{3}{|c|}{$\begin{array}{l}\left.\text { Flavonoid content (mgQE } 100 \mathrm{~g}^{-1}\right) \\
\text { Goat manure level (kg per-plant) }\end{array}$} & \multirow{2}{*}{$\begin{array}{l}\text { The average of flavonoid } \\
\text { content by Bacillus } \\
\text { velezensis } \mathrm{B}-27 \text { treatments } \\
\left(\mathrm{mgQE} 100 \mathrm{~g}^{-1}\right)\end{array}$} \\
\hline & 0 & 5 & 10 & \\
\hline Without Bacillus velezensis B-27 & $5.04 \mathrm{~cd}$ & $5.02 \mathrm{~d}$ & $5.07 \mathrm{~cd}$ & 5.04 \\
\hline With Bacillus velezensis B-27 & $5.12 \mathrm{c}$ & $5.24 \mathrm{~b}$ & $5.35 \mathrm{a}$ & 5.24 \\
\hline $\begin{array}{l}\text { The average of flavonoid content } \\
\text { by goat manure treatments } \\
\left(\mathrm{mgQE} 100 \mathrm{~g}^{-1}\right)\end{array}$ & 5.08 & 5.13 & 5.21 & $(+)$ \\
\hline Coefficient of variance $(\%)$ & & 2.33 & & \\
\hline
\end{tabular}

Table 4 depicts that the best application was $10 \mathrm{~kg}$ goat manure per-plant combined with Bacillus velezensis $\mathrm{B}-27$ that produced the highest content of flavonoid (5.35 mgEQ $\left.100 \mathrm{~g}^{-1}\right)$, followed by $5 \mathrm{~kg}$ goat manure per-plant with bacteria application (5.24 mgEQ $100 \mathrm{~g}^{-1}$ ) as the second-highest of flavonoid content. Application of Bacillus velezensis B-27 without manure produced the third highest value of flavonoid content $\left(5.12 \mathrm{mgEQ} 100 \mathrm{~g}^{-1}\right)$ that did not show a significant difference with an application of $10 \mathrm{~kg}$ goat manure per-plant without bacteria $\left(5.07 \mathrm{mgEQ} 100 \mathrm{~g}^{-1}\right)$. Then, the application of $10 \mathrm{~kg}$ goat manure per-plant only, also gave an insignificant difference with $5 \mathrm{~kg}$ goat manure per-plant without bacteria
(5.02 mgEQ $100 \mathrm{~g}^{-1}$ ). At the last, the control treatment showed the lowest flavonoid content of the all (5.04 mgEQ $\left.100 \mathrm{~g}^{-1}\right)$, which was not significantly different from an application of $5 \mathrm{~kg}$ goat manure per-plant without bacteria.

Several studies showed that Bacillus sp. could increase the flavonoid contents by some compounds in its pathway of metabolism. An in vitro assay showed that Bacillus sp. could significantly increase the flavonoid level through $\beta$-glucosidase and protease activities (Yang et al., 2019). In addition, the naringinase, an enzyme that contributes to the formation of some flavonoid compounds, is also purified from Bacillus sp. (Zhu et al., 2017). Since flavonoid compounds are not synthesized by 
the human body, consuming them from fruit becomes an alternative to supply antioxidant needs, because mainly flavonoids are the rich antioxidant resources. Naturally, the snake fruit contains flavonoid compounds that show inhibition effect to tyrosinase, the rate-limiting enzyme that provides melanin. Thus, this fruits extract is potential as a skin lightening agent (Tilaar et al., 2017). Besides, the snake fruit contains $0.31 \mathrm{mg} \mathrm{g}^{-1}$ of catechin, an important flavonoid compound, that can be used for several purposes in the field of health (Gorinstein et al., 2011).

\section{Total phenol contents}

The total phenol content represents whole phenol group compound contained in the snake fruit treated with goat manure and Bacillus velezensis $\mathrm{B}-27$. The result shows that the interaction of goat manure level and Bacillus velezensis B-27 application raised total phenol (Table 5).

Table 5. Total phenol content of snake fruit by applications of goat manure and Bacillus velezensis B-27

\begin{tabular}{|c|c|c|c|c|}
\hline \multirow{2}{*}{$\begin{array}{l}\text { Bacillus velezensis B-27 } \\
\text { applications }\end{array}$} & \multicolumn{3}{|c|}{$\begin{array}{c}\text { Total phenol content }\left(\mathrm{mgGAE} 100 \mathrm{~g}^{-1}\right) \\
\text { Goat manure level (kg per-plant) }\end{array}$} & \multirow{2}{*}{$\begin{array}{c}\text { The average of total } \\
\text { phenol content by } \\
\text { Bacillus velezensis } \\
\text { B-27 treatments } \\
\left(\mathrm{mgQE} 100 \mathrm{~g}^{-1}\right)\end{array}$} \\
\hline & 0 & 5 & 10 & \\
\hline Without Bacillus velezensis B-27 & $4.13 \mathrm{c}$ & $4.14 \mathrm{bc}$ & $4.22 \mathrm{bc}$ & 4.16 \\
\hline With Bacillus velezensis B-27 & $4.26 \mathrm{~b}$ & $4.30 \mathrm{~b}$ & $4.44 \mathrm{a}$ & 4.33 \\
\hline $\begin{array}{l}\text { The average of total phenol } \\
\text { content by goat manure treatments } \\
\left(\mathrm{mgQE} 100 \mathrm{~g}^{-1}\right)\end{array}$ & 4.14 & 4.22 & 4.33 & $(+)$ \\
\hline Coefficient of variance $(\%)$ & & 2.59 & & \\
\hline
\end{tabular}

The positive interaction between two factors brought $10 \mathrm{~kg}$ of goat manure per-plant with Bacillus velezensis B-27 became the best treatment to increase total phenol content (4.44 mgEGA $\left.100 \mathrm{~g}^{-1}\right)$. The second highest of total phenol was treatment using $5 \mathrm{~kg}$ goat manure per-plant combined with Bacillus velezensis B-27 (4.30 mgEGA $100 \mathrm{~g}^{-1}$ ). This value was not significantly different from the total phenolic of Bacillus velezensis $\mathrm{B}-27$ without manure application (4.26 mgEGA $\left.100 \mathrm{~g}^{-1}\right)$. Then, treatment with $10 \mathrm{~kg}$ goat manure per-plant without bacteria (4.22 mgEGA $100 \mathrm{~g}^{-1}$ ) was also insignificant different with the application of Bacillus velezensis B-27 only and $5 \mathrm{~kg}$ goat manure per-plant without bacteria (4.14 mgEGA $\left.100 \mathrm{~g}^{-1}\right)$. Treatment without manure nor bacteria produced the lowest total phenol (4.13 mgEGA $100 \mathrm{~g}^{-1}$ ) that did not show significant differences with other treatments without bacteria. The lowest value of total phenol was control.

From the data, we can see that $10 \mathrm{~kg}$ of goat manure per-plant combined with Bacillus velezensis $\mathrm{B}-27$ gave the highest total phenolic value of all treatments (Table 5). This result is also supported by another study revealing that Bacillus sp. inoculation can produce indole-3acetic-acid (auxin) that induce plant growth and improve the synthesis of amino acids like phenylalanine and tyrosine, which enter shikimic acid pathway, which has the responsibility to product some phenolic compounds such as gallic acid, ferulic acid and p-coumaric acid (Cisternas-Jamet et al., 2020; Sutini et al., 2020). Gowtham et al. (2018) also showed that Bacillus sp. treatment was in line with higher activity of some enzymes like phenylalanine ammonialyase (PAL) and polyphenol oxidase (PPO), which play a role on phenolics biosynthesis and other enzymes like peroxidase (POX) and $\beta$-1,3-glucanase, which show antioxidant activity. Since phenolic compounds naturally act as plant protection compounds, the improvement of these compounds also facilitates the plant's ability to overcome some diseases or abiotic stresses.

The snake fruit is one of the indigenous fruits becoming popular in Indonesia as the good fiber and antioxidant sources. The high antioxidant value by Bacillus velezensis B-27 and goat 
manure treatment correlates with a phytochemical compound contained. The strong correlation between antioxidant, total phenolic and flavonoid content shows that the antioxidant activity of the snake fruit is mostly affected by several compounds from the phenolic and flavonoid groups. In line with the results, a study that was undertaken by Esmaeili et al. (2015) showed a strong correlation between phenol and flavonoid contents with DPPH radical scavenging activities in red clover. Total phenolic and flavonoid contents show a remarkable scavenging effect on DPPH free radicals, although more studies with in vivo model should be done to examine antioxidant activity in plants and the relationship between phenolic and flavonoid compounds and antioxidant activity by using other methods to clarify the use of compounds as sources of antioxidants (Phuyal et al., 2020).

\section{CONCLUSIONS}

In conclusion, the application of Bacillus velezensis B-27 combined with goat manure can increase the antioxidant level, flavonoid and total phenol contents. The best combination treatment was $10 \mathrm{~kg}$ goat manure per-plant with bacteria. Besides, the size of fruit is also improved by $10 \mathrm{~kg}$ goat manure per-plant enriched with Bacillus velezensis B-27. Advanced research about the effect of Bacillus velezensis B-27 on fruit development seems to be promising to propose genomic and proteomic changes caused by the bacteria activity.

\section{ACKNOWLEDGEMENT}

The authors would like to thank the Department of Agronomy, Universitas Gadjah Mada, for funding this research in 2019 with the research grant contract number 2422/PN/ $\mathrm{TU} / 2019$. We are also thankful to the organic farmers of snake fruit that assisted all research activities in organic snake fruit orchad of Turi Village, Sleman, Special Region of Yogyakarta.

\section{REFERENCES}

Adijaya, I. N., \& Yasa, I. M. R. (2015). Pengaruh pupuk organik dan penjarangan buah terhadap produktivitas salak gula pasir. Jurnal Pengkajian dan Pengembangan Teknologi Pertanian, 18(2), 195-206. Retrieved from http://ejurnal.litbang.pertanian .go.id/index.php/jpengkajian/article/view/49 17

Albanchez, E. G., García-Villaraco, A., Lucas, J. A., Gutierrez, F. J., \& Ramos-Solano, B. (2018). Priming fingerprint induced by Bacillus amyloliquefaciens QV15, a common pattern in Arabidopsis thaliana and in field-grown blackberry. Journal of Plant Interactions, 13(1), 398-408. https://doi.org/ 10.1080/17429145.2018.1484187

Ali, M. B., \& McNear, D. H. (2014). Induced transcriptional profiling of phenylpropanoid pathway genes increased flavonoid and lignin content in Arabidopsis leaves in response to microbial products. BMC Plant Biology, 14(1), 84. https://doi.org/10.1186/1471-222914-84

Belwal, T., Pandey, A., Bhatt, I. D., Rawal, R. S., \& Luo, Z. (2019). Trends of polyphenolics and anthocyanins accumulation along ripening stages of wild edible fruits of Indian Himalayan region. Scientific Reports, 9(1), 5894. https://doi.org/10.1038/s41598-019-422 70-2

BPS - Statistics Sleman Regency. (2018). Turi Subdistrict in Figures 2018. Retrieved from https://slemankab.bps.go.id/publication/2018/ 09/26/cb6cfd73532dc5953180edf9/kecamatan -turi-dalam-angka-2018.html

Chang, C. C., Yang, M. H., Wen, H. M., \& Chern, J. C. (2002). Estimation of total flavonoid content in propolis by two complementary colometric methods. Journal of Food and Drug Analysis, 10(3), 178-182. https://doi.org /10.38212/2224-6614.2748

Chatzistathis, T., Papadakis, I. E., Papaioannou, A., Chatzissavvidis, C., \& Giannakoula, A. (2020). Comparative study effects between manure application and a controlled-release fertilizer on the growth, nutrient uptake, photosystem II activity and photosynthetic rate of Olea europaea L. (cv. 'Koroneiki'). Scientia Horticulturae, 264, 109176. https:// doi.org/10.1016/j.scienta.2020.109176

Cisternas-Jamet, J., Salvatierra-Martínez, R., Vega-Gálvez, A., Stoll, A., Uribe, E., \& Goñi, M. G. (2020). Biochemical composition as a function of fruit maturity stage of bell pepper (Capsicum annum) inoculated 
with Bacillus amyloliquefaciens. Scientia Horticulturae, 263, 109107. https://doi.org/ 10.1016/j.scienta.2019.109107

Esmaeili, A. K., Taha, R. M., Mohajer, S., \& Banisalam, B. (2015). Antioxidant activity and total phenolic and flavonoid content of various solvent extracts from in vivo and in vitro grown Trifolium pratense L. (Red Clover). BioMed Research International, 2015, 643285. https://doi.org/10.1155/2015/ 643285

Fendiyanto, M. H., Satrio, R. D., \& Darmadi, D. (2020). Metabolic profiling and pathway analysis in red arillus of Salacca sumatrana demonstrate significant pyruvate, sulfur, and fatty acid metabolisms. Biodiversitas, 21(9), 4361-4368. https://doi.org/10.13057/ biodiv/d210955

Gichaba, V. M., Ndukhu, H. O., Muraya, M., Odilla, G. A., \& Ogolla, F. O. (2020). Preparation and evaluation of goat manurebased vermicompost for organic garlic production in Manyatta Sub-county, Kenya. International Journal of Environment, Agriculture and Biotechnology, 5(1), 51-55. https://doi.org/10.22161/ijeab.51.7

Gorinstein, S., Poovarodom, S., Leontowicz, M., Namiesnik, J., \& Vearasilp, S. (2011). Antioxidant properties and bioactive constituents of some rare exotic Thai fruits and comparison with conventional fruits: In vitro and in vivo studies. Food Research International, 44(7), 2222-2232. https://doi. org/10.1016/j.foodres.2010.10.009

Gorinstein, S., Haruenkit, R., Poovarodom, S., Park, Y. S., Vearasilp, S., Suhaj, M., Ham, K. S., Heo, B. G., Cho, J. Y., \& Jang, H. G. (2009). The comparative characteristics of snake and kiwi fruits. Food and Chemical Toxicology, 47(8), 1884-1891. https://doi.org/ 10.1016/j.fct.2009.04.047

Gowtham, H. G., Murali, M., Brijesh Singh, S., Lakshmeesha, T.R., Narasimha Murthy, K., Amruthesh, K.N., \& Niranjana, S. R. (2018). Plant growth promoting rhizobacteria-Bacillus amyloliquefaciens improves plant growth and induces resistance in chilli against anthracnose disease. Biological Control, 126, 209-217. https://doi.org/10.1016/j.biocontrol.2018.05.0 22
Gül, A., Kidoglu, F., \& Tüzel, Y. (2008). Effects of nutrition and Bacillus amyloliquefaciens on tomato (Solanum lycopersicum, L.) growing in perlite. Spanish Journal of Agricultural Research, 6(3), 422-429. https:// doi.org/10.5424/sjar/2008063-335

Handajaningsih, M., Hasanudin, Saputra, H. E., Marwanto, \& Yuningtyas, A. P. (2019). Modification of growing medium for container melon (Cucumis melo L.) production using goat manure and dolomite. International Journal on Advanced Science, Engineering and Information Technology, 9(2), 441-447. https://doi.org/10.18517/ijaseit.9.2.2543

Hariadi, Y. C., Nurhayati, A. Y., \& Hariyani, P. (2016). Biophysical monitoring on the effect on different composition of goat and cow manure on the growth response of maize to support sustainability. Agriculture and Agricultural Science Procedia, 9, 118-127. https://doi.org/10.1016/j.aaspro.2016.02.135

Hill-Cottingham, D. G., \& Williams, R. R. (2015). Effect of time of application of fertilizer nitrogen on the growth, flower development and fruit set of Maiden apple trees, var. Lord Lambourne, and on the distribution of total nitrogen within the trees. Journal of Horticultural Science, 42(4), 319-338. https://doi.org/10.1080/00221589.1967.11514 218

Iqbal, A., Dong, Q., Wang, X., Gui, H., Zhang, H., Zhang, X., \& Song, M. (2020). Transcriptome analysis reveals differences in key genes and pathways regulating carbon and nitrogen metabolism in cotton genotypes under $\mathrm{N}$ starvation and resupply. International Journal of Molecular Sciences, 21(4), 1500. https://doi.org/10.3390/ijms21041500

Jimoh, M. O., Afolayan, A. J., \& Lewu, F. B. (2019). Antioxidant and phytochemical activities of Amaranthus caudatus L. harvested from different soils at various growth stages. Scientific Reports, 9(1), 12965. https://doi.org/10.1038/s41598-019-49276-w

Kadaikunnan, S., Rejiniemon, S. S., Khaled, J. M., Alharbi, N. S., \& Mothana, R. (2015). In-vitro antibacterial, antifungal, antioxidant and functional properties of Bacillus amyloliquefaciens. Annals of Clinical Microbiology and Antimicrobials, 
14(1), 9. https://doi.org/10.1186/s12941-0150069-1

Leontowicz, H., Leontowicz, M., Drzewiecki, J., Haruenkit, R., Poovarodom, S., Park, Y. S., Jung, S. T., Kang, S. G., Trakhtenberg, S., \& Gorinstein, S. (2006). Bioactive properties of Snake fruit (Salacca edulis Reinw) and Mangosteen (Garcinia mangostana) and their influence on plasma lipid profile and antioxidant activity in rats fed cholesterol. European Food Research and Technology, 223(5), 697-703. https://doi.org/10.1007/s00 217-006-0255-7

Li, Y., Han, L. R., Zhang, Y., Fu, X., Chen, X., Zhang, L., Mei, R., \& Wang, Q. (2013). Biological control of apple ring rot on fruit by Bacillus amyloliquefaciens 9001. Plant Pathology Journal, 29(2), 168-173. https:// doi.org/10.5423/PPJ.SI.08.2012.0125

Lyu, Y., Porat, R., Yermiyahu, U., Heler, Y., Holland, D., \& Dag, A. (2019). Effects of nitrogen fertilization on pomegranate fruit, aril and juice quality. Journal of the Science of Food and Agriculture, 100(4), 1678-1686. https://doi.org/10.1002/jsfa.10182

Mayrowani, H. (2016). Pengembangan pertanian organik di Indonesia. Forum Penelitian Agro Ekonomi, 30(2), 91-108. http://dx.doi.org/ 10.21082/fae.v30n2.2012.91-108

Mazumdar, P., Pratama, H., Lau, S. E., Teo, C. H., \& Harikrishna, J. A. (2019). Biology, phytochemical profile and prospects for snake fruit: An antioxidant-rich fruit of South East Asia. Trends in Food Science and Technology, 91, 147-158. https://doi.org/10.1016/j.tifs.20 19.06.017

Mowa, E., Akundabweni, L., Chimwamurombe, P., Oku, E., \& Mupambwa, H. A. (2017). The influence of organic manure formulated from goat manure on growth and yield of tomato (Lycopersicum esculentum). African Journal of Agricultural Research, 12(41), 3061-3067. https://doi.org/10.5897/ajar2017. 12657

Nurrochman, Trisnowati, S., \& Muhartini, S. (2013). Pengaruh pupuk kalium klorida dan umur penjarangan buah terhadap hasil dan mutu salak (Salacca zalacca (Gaertn.) Voss) 'Pondoh Super.' Vegetalika, 2(1), 54-65.
Retrieved from https://jurnal.ugm.ac.id/index. php/jbp/article/view/1618

Oubihi, A., Hosni, H., Nounah, I., Ettouil, A., Harhar, H., Alaoui, K., Ouhssine, M., \& Guessous, Z. (2020). Phenolic content, antioxidant activity, anti-inflammatory potential, and acute toxicity study of Thymus leptobotrys Murb. extracts. Biochemistry Research International, 2020, 8823209. https://doi.org/10.1155/2020/8823209

Phuyal, N., Jha, P. K., Raturi, P. P., \& Rajbhandary, S. (2020). In vitro Antibacterial activities of methanolic extracts of fruits, seeds, and bark of Zanthoxylum armatum DC. Journal of Tropical Medicine, 2020, 2803063. https://doi.org/10.1155/2020/28030 63

Pisoschi, A. M., Pop, A., Iordache, F., Stanca, L., Predoi, G., \& Serban, A. I. (2021). Oxidative stress mitigation by antioxidants An overview on their chemistry and influences on health status. European Journal of Medicinal Chemistry, 209, 112891. https:// doi.org/10.1016/j.ejmech.2020.112891

Rahma, A. A., Suryanti, Somowiyarjo, S., \& Joko, T. (2020). Induced disease resistance and promotion of shallot growth by Bacillus velezensis B-27. Pakistan Journal of Biological Sciences, 23(9), 1113-1121. https: //dx.doi.org/10.3923/pjbs.2020.1113.1121

Rahman, M., Rahman, M., Sabir, A. A., Mukta, J. A., Khan, M. M. A., Mohi-Ud-Din, M., Miah, M. G., \& Islam, M. T. (2018). Plant probiotic bacteria Bacillus and Paraburkholderia improve growth, yield and content of antioxidants in strawberry fruit. Scientific Reports, 8(1), 2504. https:// doi.org/10.1038/s41598-018-20235-1

Reddy, I. B., Chaitra, B. M., Kammar, S. C,. \& Chethana, M. C. (2019). Studies on effect of PGPRS and organic matter on nutrient content and antioxident activity of Morinda citrifolia L. Trends in Biosciences, 8(24), 6897-6899. Retrieved from https://www.researchgate.net/ publication/331166294_Studies_on_Effect_of _PGPRS_and_Organic_Matter_on_Nutrient_ content_and_Antioxident_Activity_of_Morin da_citrifolia_L

Saleh, M. S. M., Siddiqui, M. J., Mediani, 
A., Ismail, N. H., Ahmed, Q. U., So'ad, S. Z. M., \& Saidi-Besbes, S. (2018). Salacca zalacca: A short review of the palm botany, pharmacological uses and phytochemistry. Asian Pacific Journal of Tropical Medicine, 11(12), 645-652. https://doi.org/10.4103/1995 $-7645.248321$

Salehi, A., Fallah, S., Zitterl-Eglseer, K., Kaul, H. P., Surki, A. A., \& Mehdi, B. (2019). Effect of organic fertilizers on antioxidant activity and bioactive compounds of fenugreek seeds in intercropped systems with buckwheat. Agronomy, 9(7), 367. https://doi.org/10.3390/ agronomy 9070367

Santos-Sánchez, N. F., Salas-Coronado, R., Hernández-Carlos, B., \& VillanuevaCañongo, C. (2019). Shikimic acid pathway in biosynthesis of phenolic compounds. In Plant physiological aspects of phenolic compounds, (pp. 35-50). London, UK: IntechOpen. https://doi.org/10.5772/intechop en. 83815

Sharma, K., Sharma, S., \& Prasad, S. R. (2019). PGPR: Renewable tool for sustainable agriculture. International Journal of Current Microbiology and Applied Sciences, 8(1), 525-530. https://doi.org/10.20546/ijcmas.201 9.801 .058

Song, X., Liu, M., Wu, D., Griffiths, B. S., Jiao, J., Li, H., \& Hu, F. (2015). Interaction matters: Synergy between vermicompost and PGPR agents improves soil quality, crop quality and crop yield in the field. Applied Soil Ecology, 89, 25-34. https:// doi.org/10.1016/j.apsoil.2015.01.005

Suica-Bunghez, I. R., Teodorescu, S., Dulama, I. D., Voinea, O. C., Imionescu, S., \& Ion, R. M. (2016). Antioxidant activity and phytochemical compounds of snake fruit (Salacca zalacca). IOP Conference Series: Materials Science and Engineering, 133, 012051. https://doi.org/10.1088/1757-899X/1 $33 / 1 / 012051$

Sutini, Widiwurjani, Augustien, N., Purwanto, D. A., \& Muslihatin, W. (2020). Secondary metabolites production of epigallocatechin gallate through in vitro culture of Camellia sinensis 1 with cinnamic acid precursors. AIP Conference Proceedings, 2231, 040082. https://doi.org/10.1063/5.0002565
Tan, S. S., Tan, S. T., \& Tan, C. X. (2020). Antioxidant, hypoglycemic and antihypertensive properties of extracts derived from peel, fruit and kernel of Salak. British Food Journal, 122(10), 3029-3038. https:// doi.org/10.1108/BFJ-03-2020-0233

Tilaar, A., Ranti, A., \& Mun'im, A. (2017). The efficacy study of snake fruit (Salacca edulis Reinw var. Bongkok) extract as skin lightening agent. Pharmacognosy Journal, 9(2), 235238. https://doi.org/10.5530/pj.2017.2.39

Tiwari, S., Prasad, V., \& Lata, C. (2019). Bacillus: Plant growth promoting bacteria for sustainable agriculture and environment. In New and Future Developments in Microbial Biotechnology and Bioengineering: Microbial Biotechnology in Agro-environmental Sustainability (pp. 43-55). Elsevier. https: //doi.org/10.1016/B978-0-444-64191-5.00003 $-1$

Wang, C., Zhao, D., Qi, G., Mao, Z., Hu, X., Du, B., Liu, K., \& Ding, Y. (2020). Effects of Bacillus velezensis FKM10 for promoting the growth of Malus hupehensis Rehd. and inhibiting Fusarium verticillioides. Frontiers in Microbiology, 10, 2889. https://doi.org/ 10.3389/fmicb.2019.02889

Yang, J., Wu, X. bin, Chen, H. lei, Sunwaterhouse, D., Zhong, H. bo, \& Cui, C. (2019). A value-added approach to improve the nutritional quality of soybean meal byproduct: Enhancing its antioxidant activity through fermentation by Bacillus amyloliquefaciens SWJS22. Food Chemistry, 272, 396-403. https://doi.org/10.1016/j.food chem.2018.08.037

Zargoosh, Z., Ghavam, M., Bacchetta, G., \& Tavili, A. (2019). Effects of ecological factors on the antioxidant potential and total phenol content of Scrophularia striata Boiss. Scientific Reports, 9(1), 16021. https://doi.org/ 10.1038/s41598-019-52605-8

Zhu, Y., Jia, H., Xi, M., Xu, L., Wu, S., \& Li, $X$. (2017). Purification and characterization of a naringinase from a newly isolated strain of Bacillus amyloliquefaciens 11568 suitable for the transformation of flavonoids. Food Chemistry, 214, 39-46. https://doi.org/ 10.1016/j.foodchem.2016.06.108 